\title{
Impedimetric Nanobiosensor for the Detection of Sequence-Selective DNA Hybridization
}

\section{Dizi Seçimli DNA Hibridizasyonu için Impedimetrik Nanobiyosensör}

\section{Research Article}

\section{Merve Muti ${ }^{12,3}$, Mihrican Muti ${ }^{4 *}$, Arzum Erdem ${ }^{3}$}

${ }^{1}$ Analytical Chemistry Dept., Faculty of Pharmacy, Ege University, Izmir, Turkey. ${ }^{2}$ Department of Material Science and Engineering, Ege University, Izmir, Turkey. ${ }^{3}$ Söke Vocational School, Mechatronics Program, Adnan Menderes University, Aydın, Turkey. ${ }^{4}$ Department of Chemistry, Faculty of Arts and Sciences, Adnan Menderes University, Aydın, Turkey.

\section{A B S T R AC T}

\begin{abstract}
5 -amino-2-mercapto-1,3,4-thidiazole (AMT) enriched gold nanoparticles (AuNPs) modified impedimetric 5 sensors were developed for the electrochemical monitoring of sequence-selective DNA hybridization related to Hepatitis B virus (HBV). AMT-AuNP-PGEs presented more repeatable impedimetric responses and provided a suitable surface for more DNA binding onto AMT-AuNPs-PGE surface. The selectivity of DNA biosensor modified with AMT-AUNP was investigated in the presence of target DNA, or the other DNA sequences; e.g, noncomplementary (NC), or mismatch (MM) DNA sequences. The detection limit was calculated as $0.86 \mu \mathrm{g} / \mathrm{mL}$.
\end{abstract}

\section{Key Words}

Gold nanoparticles, 5-amino-2-mercapto-1,3,4-thidiazole, DNA hybridization, impedimetric sensor.

\section{Ö z}

\begin{abstract}
A Itın nanopartiküller (AuNPs) ile zenginleştirilmiş 5-amino-2-mercapto-1,3,4-thidiazole (AMT) modifiye imA pedimetrik sensörler, Hepatit B virüsüne (HBV) ilişkin dizi seçimli DNA hibridizasyonunun elektrokimyasal olarak izlenmesi için geliştirilmiştir. AMT-AuNP-PGE ler daha fazla miktarda DNA'nın AMT-AuNPs-PGE yüzeyine bağlanması için uygun bir yüzey sağlamış ve daha tekrarlanabilir impedimetrik sinyaller vermiştir. AMT-AuNP ile modifiye edilmiş DNA biyosensörlerin seçimliliği, hedef DNA, veya diğer DNA dizileri; rastgele dizi (NC), mutasyonlu dizi (MM) varlığında test edilmiştir. Tayin sınırı $86 \mu \mathrm{g} / \mathrm{mL}$ olarak hesaplanmıştır.
\end{abstract}

\section{Anahtar Kelimeler}

Altın nanopartiküller, 5-amino-2-mercapto-1,3,4-thidiazole, DNA hibridizasyonu, impedimetrik sensor.

Article History: Received: Dec 22, 2017; Revised: Jan 16, 2018; Accepted: Sep 26, 2018; Available Online: Nov 13, 2018.

DOI: $10.15671 /$ HJBC.2018.257

Correspondence to: M. Muti, Department of Chemistry, Faculty of Arts and Sciences, Adnan Menderes University, Aydın, Turkey. 


\section{INTRODUCTION}

- lectrochemical biosensors exhibit many - advantages in the sensing technology. Some of them are high sensitivity and specificity, smaller analyte volume, easy fabrication, rapidity, low cost, and the possibility of instrument miniaturization [1-4].

The inert metals are generally used for the design of electrochemical sensors since they exhibit excellent electrochemical behaviors and are stable in biological environments. The electrodes that have been most preferentially used for electrochemical biosensors are gold [5,6], platinum [7], and glassy carbon $[8,9]$, although these electrodes are very expensive, hard for treatment, and time consuming development process. Especially in routine analysis, the use of those kinds of electrodes has not been affordable and practical to use. Therefore, there is a considerable interest to the design of these (nano) materials and apply them for surface modification of different electrodes.

Pencil graphite electrodes (PGEs) have been preferentially used in electrochemical biosensor studies owing to being cheaper and disposable [10-14]. After modification of these single-use electrodes by different nanomaterials, more sensitive measurements could be obtained by nanomaterials based PGEs.

There are different ways in order to prepare Au nanoparticles immobilized electrodes. One of them is to use Au nanoparticles as colloidal, and another one is modifying electrode surface by Au nanoparticles by electrodeposition. The Au nanoparticles, which were immobilized onto the electrode surface, can be conjugated with the analyte (i.e. antibodies or ssDNA). The sensing interface that contains $A u$ nanoparticles, offers increased electrode surface, and chemical accessibility to the analyte through these networks.

The most common applications of Au nanoparticles to biosensor development are related to the specific immobilization of proteins, oligonucleotides etc. onto the modified surfaces [15-26].

An impedimetric DNA sensor based on the displacement of gold nanoparticles (AuNPs) by target DNA was developed by Gao et al. [27] for the high sensitive detection of DNA hybridization. In their study, a thiol linked ssDNA was immobilized onto the gold electrode surface after that positively charged Au nanoparticles in $5 \mathrm{~nm}$ particle size were attached to the immobilized thiol linked ssDNA by electrostatic interaction. It was reported that the decrease in the electron transfer resistance (Rct) obtained after Au nanoparticle modification. The hybridization of target ssDNA was occurred by displacement of AuNPs by target ssDNA and this led to an increase in Rct value [27].

Another impedimetric biosensor based on $\mathrm{Au}$ nanoparticles was introduced by Rezaei et al. The stainless steel (SS) working electrode was modified with 3-aminopropyltriethoxysilane (APTES) and then AuNP was deposited onto the APTES modified electrode by electrochemical method. The resulting impedimetric immunosensor was used for the determination of doxorubicin by immobilizing specific monoclonal antibodies on the surface of APTES-gold nanoparticle modified electrode [28].

A different immunosensor based gold nanoparticle was also developed for the determination of Insulin-like growth factor-1 (IGF-1) resulting with a high sensitivity. In this modification process, first, 1,6-hexanedithiol (HDT) was immobilized onto the gold electrode surface, and the HDT gold electrodes were then dipped up in colloidal gold nanoparticles solution for $44 \mathrm{~h}$ [29]. The carboxyl functionalized multi-walled carbon nanotubes modified screen-printed electrodes were used as the platforms for impedimetric detection of hybridization related to sequence specific for transgenic insect-resistant Bt maize. After hybridization, streptavidin modified gold nanoparticles were used for signal amplification [30].

In our study, disposable pencil graphite electrodes were firstly modified with 5-amino-2mercapto-1,3,4-thidiazole (AMT-PGEs) and then AMT-PGEs were modified using gold nanoparticles (AuNPs) by the specific interaction of thiol groups of AMT with gold.

These electrodes were then applied for the electrochemical monitoring of sequence-selective 
nucleic acid hybridization related to Hepatitis B virus (HBV). The PGEs are used as disposable, which is also very important for fast and cost-effective monitoring of genetic diseases under the scope of DNA biosensors.

To the best of our knowledge, this is the first report presenting the single-use electrochemical biosensor modified with AMT-AuNP developed for impedimetric detection of HBV DNA hybridization. The surface characterization of these electrodes was performed by scanning electron microscopy (SEM). All experiments were performed by using electrochemical impedance spectroscopy (EIS) technique and the resistance of charge transfer $\left(R_{c t}\right)$ was measured. The effect of changes upon to biosensor response was explored such as the dilution rate of AuNP, probe DNA concentration, target DNA concentration as well as selectivity of AMT-AuNP modified DNA biosensor.

\section{MATERIALS and METHODS Apparatus}

All impedimetric measurements were performed by using IVIUM Compact Stat Plus Module connected to a conventional three electrode system. Pencil graphite electrode (PGE) was used as working electrode. The pencil graphite leads were obtained from Live Co. (Tombow, type $\mathrm{HB}, 0.5 \mathrm{~mm}$ diameter). $\mathrm{Ag} / \mathrm{AgCl} / \mathrm{KCl}$ reference electrode (BAS, Model RE-5B, W. Lafayette, USA) and a platinum wire as the auxiliary electrode. During EIS measurements the electrochemical cell was kept in the Faraday cage (EF-1085 C3).

\section{Chemicals}

Gold nanoparticles were purchased from Aldrich as colloidal (10 $\mathrm{nm}$ in particle size). AMT was purchased from Sigma-Aldrich. Dimethylformamide (DMF) was purchased from Merck.

The synthetic oligonucleotide was purchased from TIB-MOLBIOL (Berlin, Germany). These base sequences are:

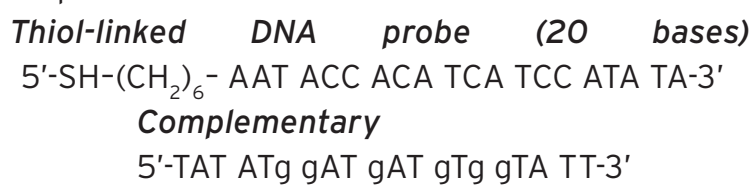

\section{Single-base mismatch (MM): \\ 5'-TAT cTg gAT gAT gTg gTA TT-3' \\ Noncomplementary (NC):}

5'-AAT ACC TgT ATT CCT CgC CTg TC-3'

Stock solutions of oligonucleotide $(500 \mu \mathrm{g} / \mathrm{mL})$ were prepared in Tris-EDTA buffer solution (TE, $\mathrm{pH}: 8.00)$ and kept frozen. The dilution of the probe solutions was carried out in $0.5 \mathrm{M}$ acetate buffer solution (ABS) containing $20 \mathrm{mM} \mathrm{NaCl}$ $(\mathrm{pH}: 4.80)$. All other chemicals were in analytical reagent grade and they were supplied from Sigma and Merck. Ultrapure water was used throughout the experiments.

\section{Procedure}

\section{Preparation of AuNP-AMT-PGE and Thiol Linked Probe Immobilization onto the Surfaces of this Electrode}

PGEs were first electrochemically pretreated in $\mathrm{ABS}$ by applying $+1.40 \mathrm{~V}$ for $30 \mathrm{~s}$. Each pretreated pencil lead was then immersed into the vials containing $110 \mu \mathrm{L}$ of $3000 \mu \mathrm{g} / \mathrm{mL}$ freshly prepared AMT solution for an hour to make an AMT layer on the electrode surface [31]. Each of this AMT modified PGEs were placed at upside down position in dark for 30 min to allowed to dry. AMT PGEs were later immersed into the vials containing $110 \mu \mathrm{L}$ of $1 / 10$ diluted AuNP solution for 1 hour. After these procedures, the modified electrodes were immersed into $50 \mu \mathrm{g} / \mathrm{mL}$ of DNA probe solution for an hour. Each of the electrodes was then dipped into the ABS solution for three times to remove nonspecifically absorbed DNA from the electrode surface before impedimetric measurements.

Fabrication of AuNP-AMT-PGEs and DNA binding strategies onto the modified electrodes is schematically illustrated in Scheme1. The use of AMT for modification step of AuNPs is important because of two active groups (amine and thiol groups) since AMT is having. Amine groups strongly bind to carboxyl groups of pretreated graphite electrodes by the electrostatic interaction. In addition, thiol groups provide strong and dense attachment to the gold nanoparticles. These gold nanoparticles provide also more and strong immobilization of thiol labeled DNA onto the electrode surface as a result of the specific interaction [31]. 


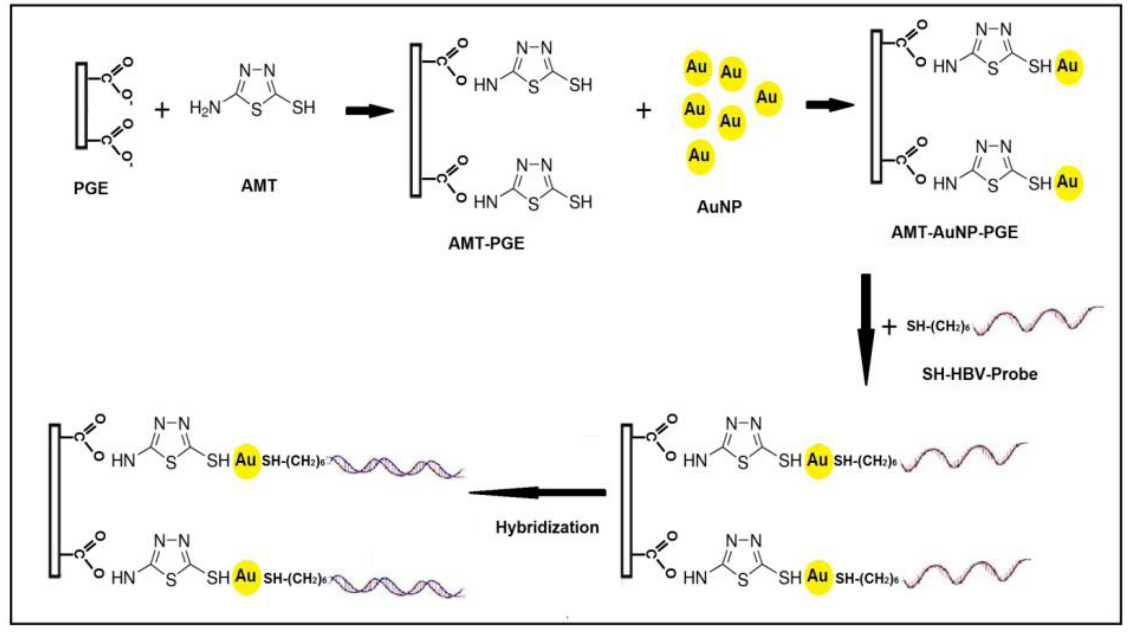

Scheme 1. Shematic illustration of the electrode preperation and DNA hybridization.

\section{Microscopic Characterization of PGEs}

Quanta $400 \mathrm{FEl}$, field emission scanning electron microscope (FE-SEM) (Tokyo, Japan) was used for microscopic characterization of unmodified, AMT modified and AuNP-AMT modified PGEs in resolution magnitude $10 \mu \mathrm{m}$ and $100 \mu \mathrm{m}$.

\section{Impedance Measurements}

Electrochemical impedance spectroscopy (EIS) measurements were performed in the presence of $2.5 \mathrm{mM} \mathrm{K}_{3}\left[\mathrm{Fe}(\mathrm{CN})_{6}\right] / \mathrm{K}_{4}\left[\mathrm{Fe}(\mathrm{CN})_{6}\right]$ (1:1) mixture as redox probe prepared in $0.1 \mathrm{M} \mathrm{KCl}$ and in the frequency range from $10^{5-10^{-1}} \mathrm{~Hz}$ at the open circuit potential of $+0.22 \mathrm{~V}$ vs. $\mathrm{Ag} / \mathrm{AgCl}$ with a sinusoidal signal of $10 \mathrm{mV}$.

\section{RESULTS and DISCUSSION}

The microscopic characterization of unmodified, AMT modified and AuNP-AMT modified PGEs were examined by using SEM in 10000X magnitude. The surface roughness of unmodified PGE was monitored clearly in Figure 1a. The smooth surface was obtained after AMT immobilization since the PGE surface was covered homogeneously

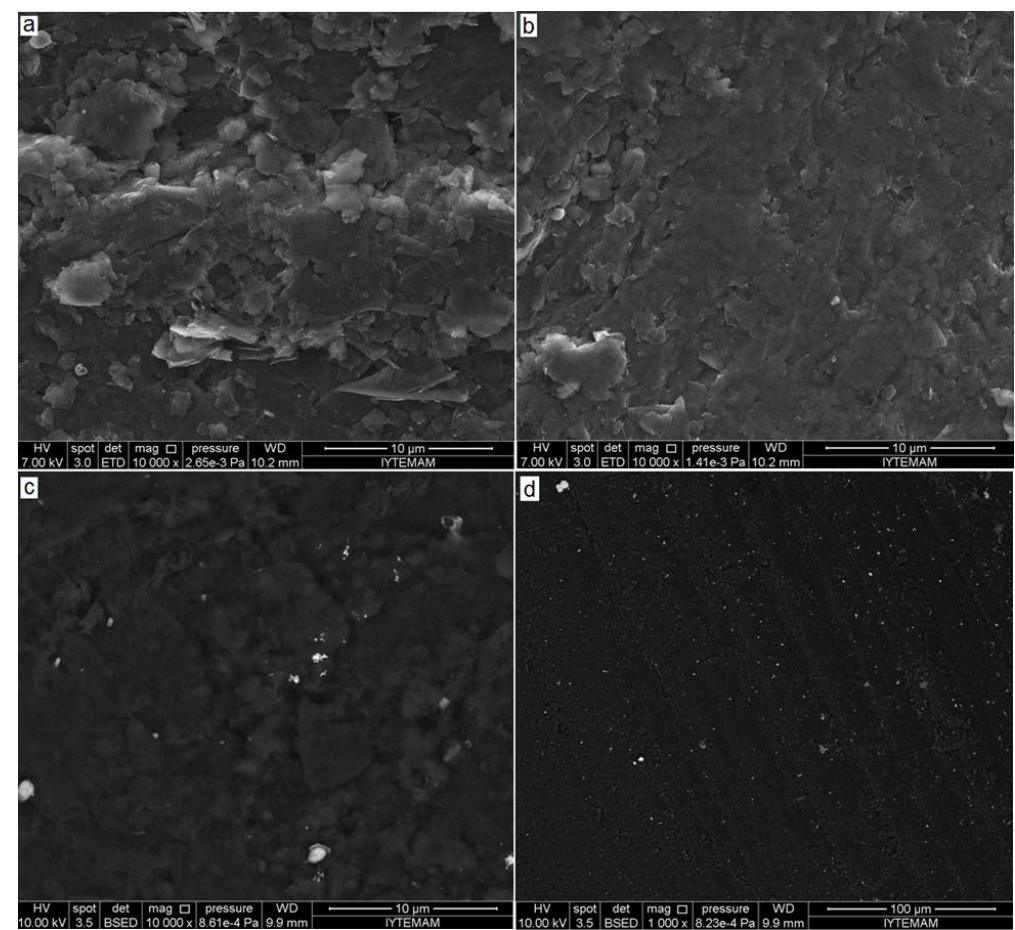

Figure 1. SEM images of (a) unmodified, (b) AMT modified and (c) AMT-AuNP modified PGE, with identical resolution, $10 \mu \mathrm{m}$ and (d) AMT-AUNP modified PGE, with identical resolution, $100 \mu \mathrm{m}$. 
with AMT film as seen in Figure 1b. After AuNP modification AuNPs were clearly seen in both higher $(10000 \mathrm{X})$ and lower magnitude (1000X) (As seen in Figure 1-c and d). The brightness of the surface was assignable to the AuNP modification. Homogeny dispersion of AuNPs was also clearly seen in Figure $1 \mathrm{c}$.

Figure 2 compares the $R_{\mathrm{ct}}$ values of $50 \mu \mathrm{g} / \mathrm{mL}$ $\mathrm{SH}-\mathrm{HBV}$ probe immobilized electrode surfaces in different stage modification. The highest and more repeatable $R_{\mathrm{ct}}$ values were obtained by using AuNPAMT-PGE. It can be explained that amine groups of AMT strongly bind with the carboxyl groups of the activated graphite and the result is the densely populated AMT presence on the electrode [31]. Accordingly more gold nanoparticles were strongly bonded via its thiol groups to the surface of AMTPGE due to the affinity of gold to thiol groups [32-36]. By using thiol linked DNA probe, more DNA bonded to the electrode surface with higher stability due to the affinity of gold to thiol groups.
The electrodes were pretreated before AMT immobilization and $3000 \mu \mathrm{g} / \mathrm{mL}$ AMT was used for full coverage of the electrode surface according to our previous study [31]. AuNP dilution ratio was studied to investigate the convenient quantity of AuNP at the modified AMT-PGE surface. AuNP dilution ratio was studied for various ranging from $1 / 3$ to $1 / 20$. The electron transfer resistance was measured both after AuNP modification and after SH-HBV probe immobilization. The results were illustrated in Figure 3. After AuNP modification owing to AuNP catalysis the electron transfer, $R_{c t}$ values decreased from $1 / 3$ dilution ratio up to $1 / 10$. After $50 \mu \mathrm{g} / \mathrm{mL} \mathrm{SH-HBV}$ probe immobilization onto the electrode surface, the $\mathrm{R}_{\mathrm{ct}}$ values increased up to $1 / 10$ due to negatively charged phosphate groups of DNA, however, the response leveled off after $1 / 10$. Thus, it was chosen as the optimum dilution ratio of AuNP for our further studies.

The effect of $\mathrm{SH}-\mathrm{HBV}$ probe concentration based on $\mathrm{R}_{\mathrm{ct}}$ values was also investigated in different $\mathrm{SH}_{-}$

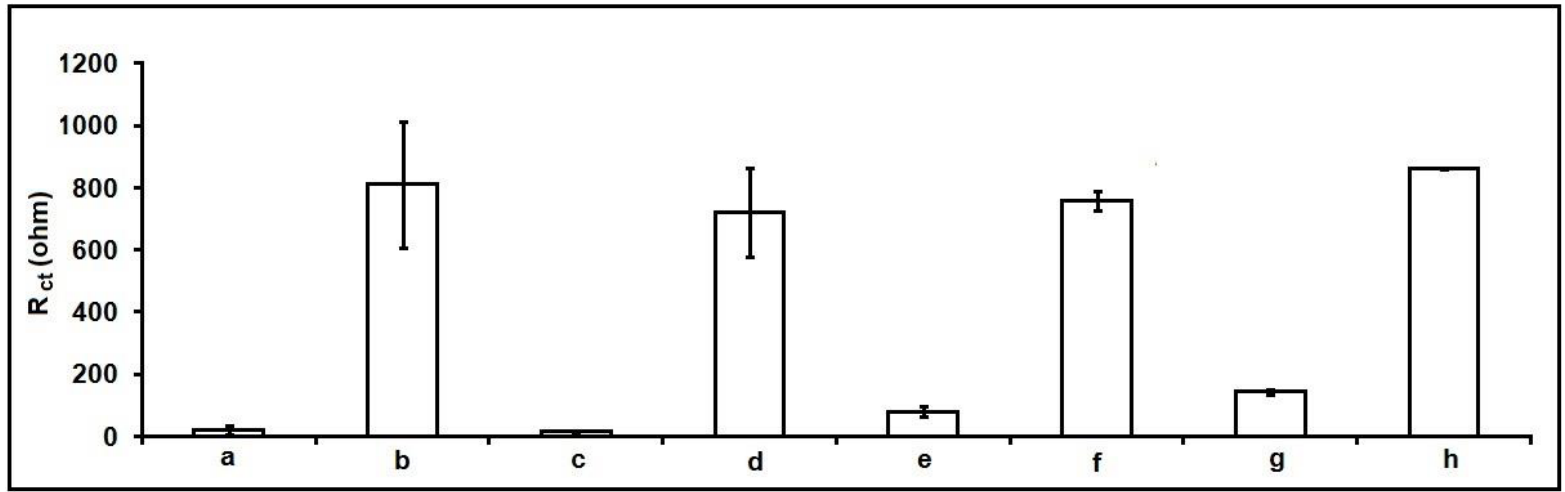

Figure 2. Histograms representing the differentiation of electron transfer resistance (Rct) of (a) unmodified PGE, (b) SHHBV probe modified PGE, (c) AMT modified PGE, (d) SH-HBV probe modified AMT-PGE, (e) AuNP modified PGE, (f) SH-HBV probe modified AuNP-PGE, (g) AuNP modified AMT-PGE and (h) SH-HBV probe modified AuNP-AMT-PGE.

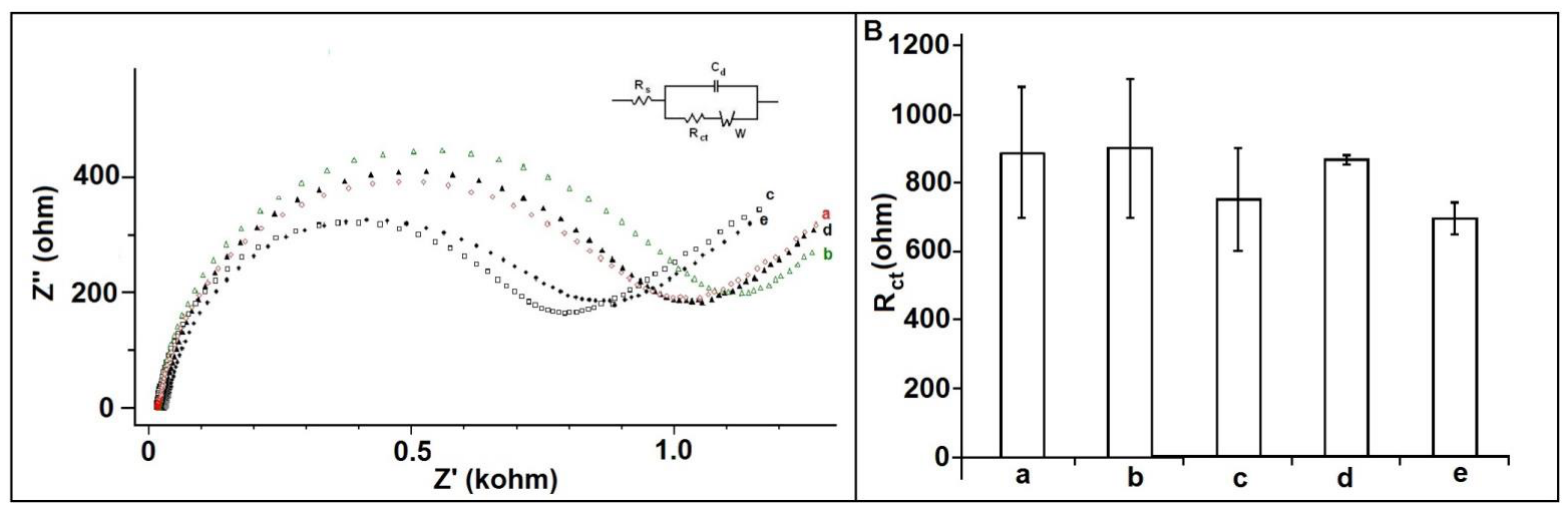

Figure 3. Nyquist (A) and histograms (B) illustrated electron transfer resistance (Rct) of AMT-AuNP-PGE modified with different dilution of AuNP. (a) $1 / 3$, (b) $1 / 5$, (c) $1 / 7$, (d) $1 / 10$ and (e) $1 / 20$. 


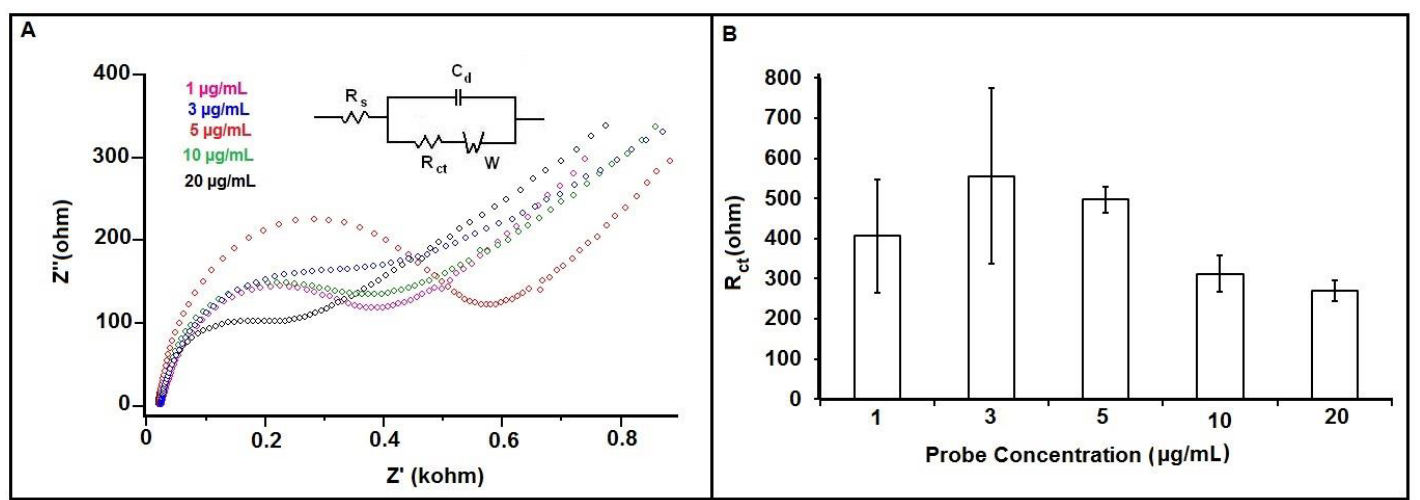

Figure 4. Nyquist (A) and histograms (B) representing Rct values of varying concentration SH-HBV probe immobilized AMT-AUNP-PGEs.

HBV probe concentrations from 1 to $20 \mu \mathrm{g} / \mathrm{mL}$ (As seen in Figure 4). After 60 min immobilization time, the highest $\mathrm{R}_{\mathrm{ct}}$ value was measured when the $\mathrm{SH}^{-}$ $\mathrm{HBV}$ probe concentration was increased to $5 \mu \mathrm{g} / \mathrm{mL}$, and then it leveled off. Since the higher and more repeatable $R_{c t}$ values were obtained in the presence of $5 \mu \mathrm{g} / \mathrm{mL}$ probe concentration $(496.7 \uparrow, \mathrm{RSD}=$ $6.4 \%, n=3)$, it was chosen as the optimum probe concentration while indicating the full coverage surface of AMT-AuNP PGE.

The selectivity of hybridization between thiol linked HBV probe and complementary (target) DNA, one base mismatch (MM) and noncomplementary (NC) was also checked by using these AMT-AuNP modified graphite sensors (As shown in Figure 5). An increase at Rct values are expected owing to increase of negatively charged phosphate groups as a result of hybridization. The highest $R_{c t}$ value was obtained in the presence of full hybridization of the probe with the complementary sequence (i.e, 857.3 $\uparrow \mathrm{RSD}=6.1 \%, \mathrm{n}=3$ ). On the other hand, a lower $\mathrm{R}_{\mathrm{ct}}$ value (i.e, almost same with the $R_{c t}$ value of probe alone) was measured in the case of hybridization of the probe with a one-base mismatch (MM). Moreover, the lowest $R_{c t}$ value was recorded in

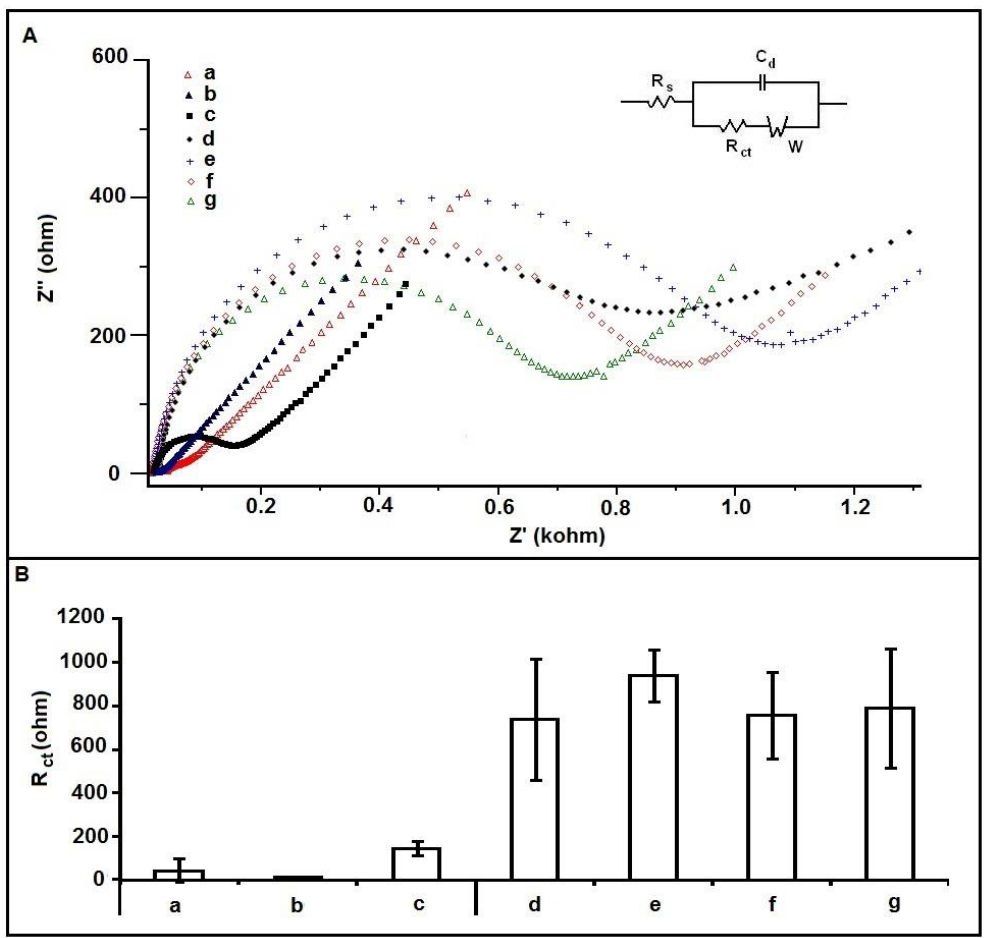

Figure 5. Nyquist $(A)$ and Histograms $(B)$ representing the Rct differentiation measured in the case of step by modification (a) unmodified PGE, (b) AMT-PGE, (c) AuNP modified AMT-PGE, (d) $5 \mu \mathrm{g} / \mathrm{mL} \mathrm{SH-HBV}$ probe modified AuNP-AMT-PGE. (e) hybridization in the presence of $10 \mu \mathrm{g} / \mathrm{mL}$ target ( $\mathrm{T}$ ), (f) hybridization with $10 \mu \mathrm{g} / \mathrm{mL}$ mismatch (MM), (g) hybridization with $10 \mu \mathrm{g} / \mathrm{mL}$ non complementary (NC) onto the AuNP-AMT-PGE surfaces. 


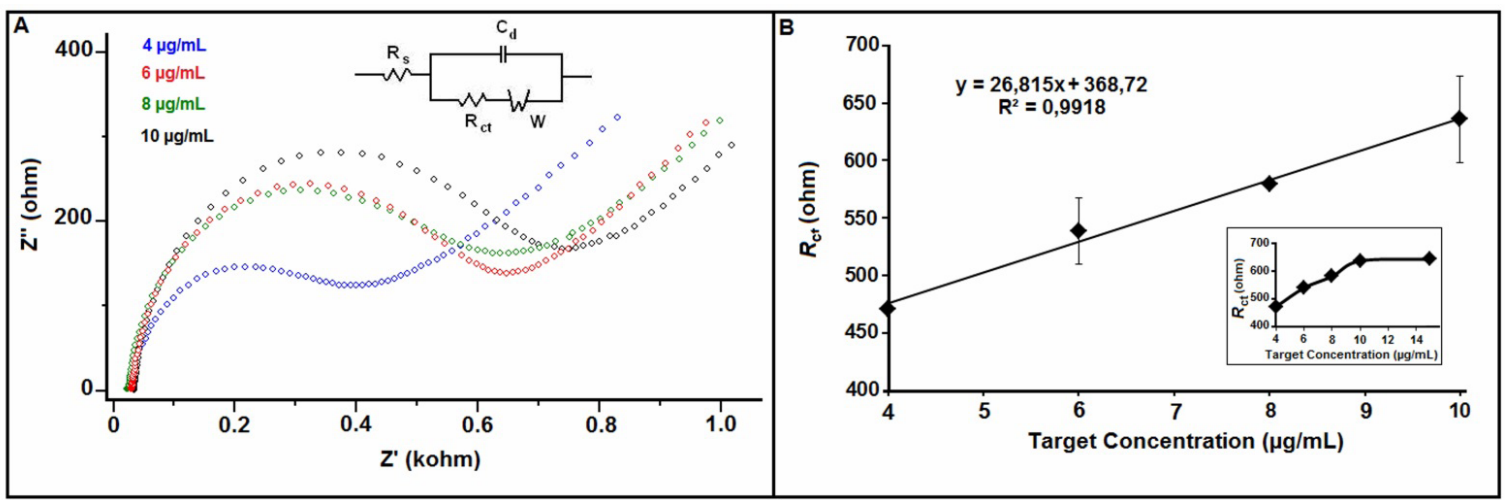

Figure 6. Nyquist (A) and calibration plot (B) representing Rct values of thiol linked HBV-DNA probe after hybridization with different concentration of target SH-HBV probe varying from 4 to $10 \mu \mathrm{g} / \mathrm{mL}$.

the presence of hybridization of the probe with a non-complementary sequence (NC). The mean of these parallel results could be attributed that no hybridization occurred between probe and $M M$, or probe and NC. AMT-AuNP PGE has exhibited a good selectivity to its target DNA in comparison to the non-complementary DNA.

The detection limit of the probe for target DNA was studied in varying target DNA concentrations from 0 to $15 \mathrm{mg} / \mathrm{L}$ (As shown in Figure 6). $R_{c t}$ value was increased up to the target concentration of $10 \mu \mathrm{g} / \mathrm{mL}$, and then it leveled off. The detection limit $(\mathrm{DL})$ is calculated as $0.86 \mu \mathrm{g} / \mathrm{mL}(0.138 \mu \mathrm{M})$ according to the method reported by Miller and Miller [37]. The relative standard deviation was calculated as $5.9 \%(n=4)$ when the target DNA concentration was $10 \mu \mathrm{g} / \mathrm{mL}$.

\section{CONCLUSION}

A novel impedimetric DNA biosensor based on AuNP-AMT modified disposable graphite electrode was introduced for the first time in our study.

The modification of these electrodes is relatively easier and this process does not require time-consuming, sophisticated instruments and special training in comparison to earlier AuNP based biosensor study [38] for the monitoring of electrochemical DNA hybridization. AMTAuNP modified electrodes have some important advantages. These electrodes used here are disposable, cost-effective and these modified electrodes can also provide enhanced DNA response, which are crucial properties for the development of DNA chip technology in future. Moreover, the treatment of the electrodes by AMT before AuNP modification can facilitate more suitable and stable surface with short modification time for AuNP binding to the electrode surface. Thus it provides more DNA binding.

AMT-AuNP modified electrodes presented a lower detection limit in contrast to earlier DNA biosensor studies based on nanomaterial modified electrodes $[4,39,40]$.

\section{References}

1. H. Chen, C. Jiang, C. Yu, S. Zhang, B. Liu, J. Kong, Protein chips and nanomaterials for application in tumor marker immunoassays, Biosens. Bioelectron. 24 (2009) 3399-3411.

2. H. Ju, X. Zhang, J. Wang, NanoBiosensing, Springer, New York, USA p. 425, 2011.

3. A. Erdem, Nanomaterial-based electrochemical DNA sensing strategies, Talanta, 74 (2007) 318-325.

4. Y.R. Kim, S. Bong, Y.J. Kang, Y. Yang, R.K. Mahajan, J.S. Kim, H. Kim, Electrochemical detection of dopamine in the presence of ascorbic acid using graphene modified electrodes, Biosens. Bioelectron. 25 (2010) 2366-2369.

5. Z. Linting, L. Ruiyi, L. Zaijun, X. Qianfang, F. Yinjun, L. Junkang, An immunosensor for ultrasensitive detection of aflatoxin $B$ with an enhanced electrochemical performance based on graphene/ conducting polymer/gold nanoparticles/the ionic liquid composite film on modified gold electrode with electrodeposition, Sensor Actuat B-Chem. 174 (2012) 359-365.

6. H. Karadeniz, B. Gülmez, A. Erdem, F. Jelen, M. Özsoz, E. Palecek, 2006 Echinomycin and cobaltphenanthroline as redox indicators of DNA hybridization at gold electrodes, Front. Biosci. 11 (2006) 1870-1877.

7. A.P. Deng, H. Yang, A multichannel electrochemical detector coupled with an ELISA microtiter plate for the immunoassay of 2,4-dichlorophenoxyacetic acid, Sensor Actuat. B-Chem. 124 (2007) 202-208. 
8. S. Jiang, E. Hua, M. Liang, B. Liu, G. Xie, A novel immunosensor for detecting toxoplasma gondiispecific IgM based on goldmag nanoparticles and graphene sheets, Colloid Surface B. 101 (2013) 481486.

9. Z. Liu, R. Yuan, Y. Chai, Y. Zhuo, C. Hong, H. Yang, Highly sensitive, reagentless amperometric immunosensor based on a novel redox-active organicinorganic composite film, Sensor Actuat B-Chem. 134 (2008) 625-631.

10. J. Narang, N. Malhotra, G. Singh, C.S. Pundir, Electrochemical impediometric detection of anti-HIV drug taking gold nanorods as a sensing interface, Biosens Bioelectron. 66 (2015) 332-337.

11. B. Rezaei, M.K. Boroujeni, A.A. Ensafi, Fabrication of DNA, o-phenylenediamine, and gold nanoparticle bioimprinted polymer electrochemical sensor for the determination of dopamine, Biosens. Bioelectron 66 (2015) 490-496.

12. G. Gokce, A. Erdem, C. Ceylan, M. Akgoz, Voltammetric detection of sequence-selective DNA hybridization related to Toxoplasma gondii in PCR amplicons, Talanta 149 (2016) 244-249.

13. S. Tajik, M.A. Taher, M.T. Mahani, Electrochemical determination of the anticancer drug taxol at a ds-DNA modified pencil-graphite electrode and its application as a label-free electrochemical biosensor, Talanta 134 (2015) 60-64.

14. X. Guo, Q. Wang, J. Li, J. Cui, S. Zhou, S. Hao, D. Wu, A mini-electrochemical system integrated micropipet tip and pencil graphite electrode for detection of anticancer drug sensitivity in vitro, Biosens Bioelectron. 64 (2015) 594-596.

15. M. Wang, L. Wang, H. Yuan, X. Ji, C. Sun, L. Ma, Y. Bai, T. Li, J. Li, Immunosensors Based on Layer-byLayer Self-Assembled Au Colloidal Electrode for the Electrochemical Detection of Antigen, Electroanal. 16 (2004) 757-764.

16. M. Wang, L. Wang, G. Wang, X. Ji, Y. Bai, T. Li, S. Gong, J. Li, Application of impedance spectroscopy for monitoring colloid Au-enhanced antibody immobilization and antibody-antigen reactions, Biosens Bioelectron. 19 (2004) 575-582.

17. D. Tang, R. Yuan, Y. Chai, J. Dai, X. Zhong, Y. Liu, A novel immunosensor based on immobilization of hepatitis B surface antibody on platinum electrode modified colloidal gold and polyvinyl butyral as matrices via electrochemical impedance spectroscopy, Bioelectrochemistry 65 (2004) 15-22.

18. C.Z. Li, Y. Liu, J.H.T. Luong, Impedance Sensing of DNA Binding Drugs Using Gold Substrates Modified with Gold Nanoparticles, Anal. Chem. 77 (2005) 478 485.

19. Z.S. Wu, J.S. Li, M.H. Luo, G.L. Shen, R.Q. Yu A novel capacitive immunosensor based on gold colloid monolayers associated with a sol-gel matrix, Anal. Chim Acta., 528 (2005) 235-242.

20. H. Chen, J.H. Jiang, Y. Huang, T. Deng, J.S. Li, G.L. Shen, R.Q. Yu, An electrochemical impedance immunosensor with signal amplification based on Au-colloid labeled antibody complex, Sensor. Actuat. B-Chem., 117 (2006) 211-219.
21. H. Huang, Z. Liu, X. Yang, Application of electrochemical impedance spectroscopy for monitoring allergen-antibody reactions using gold nanoparticle-based biomolecular immobilization method, Anal. Biochem. 356 (2006) 208-214.

22. H. Huang, P. Ran, Z. Liu, Impedance sensing of allergen-antibody interaction on glassy carbon electrode modified by gold electrodeposition, Bioelectrochemistry, 70 (2007) 257-262.

23. H. Tang, J. Chen, L. Nie, Y. Kuang, S. Yao, A label-free electrochemical immunoassay for carcinoembryonic antigen (CEA) based on gold nanoparticles (AUNPs) and nonconductive polymer film, Biosens. Bioelectron. 22 (2007) 1061-1067.

24. I. Szymanska, H. Radecka, J. Radecki, R. Kaliszan, Electrochemical impedance spectroscopy for study of amyloid -peptide interactions with ( $\Psi$ ) nicotine ditartrate and (-) cotinine, Biosens. Bioelectron., 22 (2007) 1955-1960.

25. S. Zhang, F. Huang, B. Liu, J. Ding, X. Xu, J. Kong, A sensitive impedance immunosensor based on functionalized gold nanoparticle-protein composite films for probing apolipoprotein A-I, Talanta, 71 (2007) 874-881.

26. J. Yang, T. Yang, Y. Feng, K. Jiao, A DNA electrochemical sensor based on nanogold-modified poly-2,6-pyridinedicarboxylic acid film and detection of PAT gene fragment, Anal. Biochem. 365 (2007) 24-30.

27. Q. Gao, W. Zhang, Y. Guo, H. Qi, C. Zhang, Highly sensitive impedimetric sensing of DNA hybridization based on the target DNA-induced displacement of gold nanoparticles attached to ssDNA probe, Electrochem. Commun., 13 (2011) 335-337.

28. B. Rezaei, E. Havakeshian, A.A. Ensafi, Stainless steel modified with an aminosilane layer and gold nanoparticles as a novel disposable substrate for impedimetric immunosensors, Biosens. Bioelectron. 48 (2013) 61-66.

29. B. Rezaei, N. Majidi, H. Rahmani, T. Khayamian, Electrochemical impedimetric immunosensor for insulin like growth factor-1 using specific monoclonal antibody-nanogold modified electrode, Biosens. Bioelectron., 26 (2011) 2130-2134.

30. A. Bonanni, M.J. Esplandiu, M. Valle, Impedimetric genosensors employing $\mathrm{COOH}$-modified carbon nanotube screen-printed electrodes, Biosens. Bioelectron., 24 (2009) 2885-2891.

31. M. Muti, A. Erdem, A.E. Karagozler, M. Soysal, 5-Amino-2-mercapto-1,3,4-thidiazole modified singleuse sensors for electrochemical DNA analysis, Colloid Surface B, 93 (2012) 116-120.

32. W. Cheng, W. Zhang, Y. Yan, B. Shen, D. Zhu, R. Lei, S. Ding, A novel electrochemical biosensor for ultrasensitive and specific detection of DNA based on molecular beacon mediated circular strand displacement and rolling circle amplification, Biosens. Bioelectron., 62 (2014) 274-279.

33. Y. Qian, C. Wang, F. Gao, Enzyme-free amplification for sensitive electrochemical detection of DNA via target-catalyzed hairpin assembly assisted current change, Talanta, 130 (2014) 33-38. 
34. C. Tersch, F. Lisdat, Label-free detection of proteinDNA interactions using electrochemical impedance spectroscopy, Electrochim. Acta, 56 (2011) 7673-7679.

35. C. Witte,F. Lisdat, Direct Detection of DNA and DNALigand Interaction by Impedance Spectroscopy, Electroanal., 23 (2011) 339-346.

36. P. Du, H. Li, Z. Mei, S. Liu, Electrochemical DNA biosensor for the detection of DNA hybridization with the amplification of $\mathrm{Au}$ nanoparticles and $\mathrm{CdS}$ nanoparticles, Bioelectrochemistry, 75 (2009) 37-43.

37. J.N. Miller and J.C. Miller, Statistics and Chemometrics for Analytical Chemistry Pearson Education, Essex, Fifth ed. p. 1212005.
38. W. Wang, X. Fan, S. Xu, J.J. Davis, X. Luo, Low fouling label-free DNA sensor based on polyethylene glycols decorated with gold nanoparticles for the detection of breast cancer biomarkers, Biosens. Bioelectron., 71 (2015) 51-56.

39. T. Yumak, F. Kuralay, M. Muti, A. Sinağ, A, Erdem, S. Abaci, Preparation and characterization of zinc oxide nanoparticles and their sensor applications for electrochemical monitoring of nucleic acid hybridization, Colloid. Surf. B, 86 (2011) 397-403.

40. M. Muti, F. Kuralay, A. Erdem, Single-walled carbon nanotubes-polymer modified graphite electrodes for DNA hybridization, Colloid. Surf. B, 91 (2012) 77-83. 
